\title{
DETERMINASI KUALITAS PELAYANAN PENDIDIKAN TERHADAP KEPUASAN LULUSAN FIKES UPNVJ TAHUN 2014
}

\author{
Tatiana Siregar, Murtiwi, Suryani Maryam* \\ *Dosen Pengajar di FIKES UPNVJ \\ tatiana siregar@yahoo.co.d, \\ murtiwisokarso@gmail.com, \\ sunni@yahoo.com
}

\begin{abstract}
Abstrak
Penelitian ini bertujuan untuk menganalisa determinasi kualitas pelayanan pendidikan terhadap kepuasan lulusan FIKES UPN "Veteran" Jakarta serta dimensi manakah yang paling penting pengaruhnya terhadap kepuasan lulusan FIKES UPN "Veteran" Jakarta. Pengambilan sampel dilakukan di Fakultas Ilmu-ilmu Kesehatan UPN "Veteran” Jakarta secara sampling sebanyak 216 mahasiswa lulusan FIKES UPNVJ. Teknik pengumpulan data menggunakan survey data primer. Data dianalisis dengan regresi berganda menggunakan Program Statistical Package for Social Studies (SPSS). Hasil penelitian menunjukkan terdapat pengaruh yang sangat signifikan dari dimensi responsiveness terhadap variabel kepuasan lulusan FIKES UPN "Veteran" Jakarta sebesar 0.243; dimensi empathy terhadap kepuasan lulusan sebesar 0,226; dimensi assurance terhadap kepuasan lulusan sebesar 0.283 , dimensi reliability terhadap kepuasan lulusan sebesar 0.222 dimana masing-masing nilai probabilitas (sig) bernilai 0,000 . Nilai beta coefficient dalam penelitian ini paling tinggi pada variabel Assurance sebesar 0,289.

Kesimpulan penelitian ini adalah dimensi responsiveness, emphaty, assurance, dan reliability berpengaruh signifikan positif terhadap kepuasan mahasiswa Fikes UPN "Veteran" Jakarta, sedangkan dimensi tangible tidak berpengaruh signifikan terhadap kepuasan mahasiswa. Dimensi yang paling penting pengaruhnya terhadap kepuasan mahasiswa yaitu Assurance, kemudian secara berurutan diikuti oleh dimensi emphaty, responsiveness, dan reliability yang hampir sama pentingnya.
\end{abstract}

Kata kunci : Tangible, Responsiveness, Emphaty, Assurance, Raliability, satisfaction of studet graduates, quality of education services

\section{Abstract}

Determination quality of education services to satisfaction of student graduates of Health Sciences Faculty of Pembangunan Nasional Veteran Jakarta University 2014.

This research aimed to analyze the determination of quality of education services to satisfaction of student graduates of Health Sciences Faculty of Pembangunan Nasional Veteran Jakarta University (UPNVJ) as well as a dimension which is the most important influence on the satisfaction of student graduates of Health sciences Faculty of UPNVJ. Sampling was done at Pembangunan Nasional Veteran Jakarta University by purposive sampling of 216 student graduates of Health sciences Faculty of UPNVJ. Survey data collection techniques using primary data. Data were analyzed by regression using the program Statistical Package for Social Studies (SPSS).

The result showed that there are very significant influence of the responsiveness dimension on the satisfaction of student graduates of Health sciences faculty of UPNVJ variables of 0.243 ; empathy dimension levels on the satisfaction of student graduates variables of 0.226 ; assurance dimension on the satisfaction of student graduates variables of 0.283 , reliability dimension on the satisfaction 
of student graduates variables of 0.222 in which each probability value (sig) worth 0.000 . Beta coefficient values in this research are highest at 0.289 for assurance dimension.

Conclusions of this research is responsiveness, emphaty, assurance, dan reliability, have a significant positive influence on satisfaction of student graduates of Health sciences faculty of Pembangunan Nasional Veteran Jakarta University while the tangible dimension does not significantly influence satisfaction of student graduates. The most important dimension influence quality of education services to satisfaction of student graduates of Health Sciences Faculty of Pembangunan Nasional Veteran Jakarta University is Assurance then sequentially followed by a dimension level of emphaty, responsiveness, dan reliability, that is almost equally important.

Key Words : Tangible, Responsiveness, Emphaty, Assurance, Raliability, satisfaction of student graduates, quality of education service

\section{Pendahuluan}

Perkembangan dunia pendidikan saat ini mengalami pertumbuhan yang pesat. Perkembangan pendidikan secara menyeluruh yang diiringi dengan perkembangan teknologi dan ilmu pengetahuan menciptakan sebuah persaingan yang semakin ketat dan tajam. Oleh karena itu dalam persaingan yang demikian, pendidikan dituntut untuk dapat memuaskan pelanggannya yaitu mahasiswa dengan menciptakan produk-produk pendidikan berkualitas sesuai dengan keinginan mahasiswa.

Dalam sebuah industri pendidikan pihak pendidikan harus benar-benar mengetahui dan memahami mengenaii industri perilaku para mahasiwa tentang apa yang dibutuhkan dan apa yang diinginkan. Disamping jal tersebut pihak pendidikan harus mampu menganalisis variabel- variabel dari pelayanan yang diberikan ke mahasiswa yang nantinya akan berpengaruh terhdap tingkat kepuasan pelanggan. Jasa pelayanan yang diberikan oleh pihak kampus belum cukup hanya sekedar sikap dan tingkah laku para karyawan dalam menghadapi mahasiswa tetapi juga harus mencakup semua kualitas pelayanan.

Kualitas pelayanan adalah sebagai ukuran seberapa bagus tingkat layanan yang diberikan mampu sesuai dengan ekspektasi pelanggan. Kualitas pelayanan dapat dipenuhi kebutuhan dan keinginan pelanggan serta ketepatan penyampaiannya untuk mengimbangi harapan pelanggan, serta ada dua faktor utama yang mempengaruhi kualitas jasa: jasa yang diharapkan (expected service) dan jasa yang dirasakan/dipersepsikan (perceived service). Berdasarkan 
pertimbangan tersebut, maka yang dibentuk dari evaluasi pengukuran keberhasilan suatu keseluruhan terhadap kinerja pendidikan, lebih banyak ditentukan perusahaan dalam jangka panjang. oleh penilaian dan persepsi mahsiswa Berdasarakan pendapat kedua penulis tentang kualitas pelayanan yang diberikan oleh lembaga pendidikan. Penyelenggaraan pendidikan selayaknya mencermati kualitas pelayanan. Kegiatan pendidikan tidak hanya diorientasikan pada hasil akhor proses pendidikan, melainkan juga melalui pembuktian akuntabilitas yang baik meliputi jaminan kualitas (quality assurance), pengendalian kualitas (quality control), dan perbaikan kualitas (quality improvement) yang berdasarkan Badan Akreditasi Nasional Perguruan Tinggi (BANPT).

Berdasarkan uraian diatas, maka perlu melakukan pengukuran kualitas pelayanan dibidang akademik dilihat dari faktor atau dimensi tangibel, responsivenss, asssurance, emphaty, dan reliability. terdahulu penulis membatasi pada unsur pokok kualitas pelayanan dan kepuasan mahasiswa. Diaharapkan dari penelitian ini dapat diketahui faktor-faktor dari variabel kualitas pelayanan yang mempengaruhi kepuasan mahasiswa.

\section{Tinjauan Teori}

\section{A. Kualitas Pelayanan (Jasa)}

Menurut Goetsch dan Davis, mendefinisikan kualitas adalah sebagai kondisi dinamis yang berhubungan dengan produk atau jasa, sumber daya manusia, proses dan lingkungan yang memenuhi atau melebihi harapan. Lavelock (2007), mendefiniskan kualitas jasa/pelayanan adalah evaluasi kognitif jangka panjang pelanggan terhadap hantaran jasa suatu perusahaan

\footnotetext{
Menurut Parasuraman bahwa kepuasan pelanggan merupakan ukuran spesifik untuk setiap transaksi, situasi atau interaksi (encounter) yang bersifat jangka pendek sedangkan kualitas pelayanan merupakan sikap
} 1. Model Kualitas Pelayanan (Jasa) Model kualitas jasa untuk menyoroti kebutuhan utama dalam menghantarkan kualitas jasa yang tinggi. Model ini mengidentifikasi 
lima kesenjangan yang menyebabkan kegagalan pengiriman jasa:

a. Kesenjangan antara harapan konsumen dan persepsi manajemen. Manajemen tidak selalu mempunyai anggapan yang besar tentang apa yang diinginkan pelangan.

b. Kesenjangan antara persepsi manajemen dan spesifikasi kualitas jasa - Manajemen mungkin mempunyai anggapan yang benar terhadap keinginan pelanggaan dan tetapi tidak menetapkan standar kinerja.

c. Kesenjangan antara spesifikasi kulitas jasa dan penghantaran jasa Personal mungkin tidak terlatih, atau tidak mampu atau tidak bersedia memenuhi standar, atau mungkin terikat dengan standar yang bertentangan.

d. Kesenjangan antara penghantaran jasa dan komunikasi eksternal harapan konsumen dipengaruhi oleh pernyataan yang dibuat oleh iklan dan perwakilan perusahaan.

e. Kesenjangan antara jasa yang diharapkan - Jasa yang dirasakan Kesenjangan terjadi ketika konsumen salah menganggap kualitas jasa. Pelanggan mengharapkan pelayanan yang baik, ternyata kenyataannya tidak

\section{Dimensi Kualitas Pelayanan}

Berdasarkan lima kesenjangan ini para periset mengembangkan kualitas pelayanan melalaui penilaian persepsi kualitas dengan skala SERVQUAL, yang terdiri dari 22 hal yaitu:

a. Keandalan (reliability) yaitu kemampuan untuk mengerjakan jasa yang dijanjikan, indikatornya :

1) Menyediakan jasa sesuai yang dujanjikan

2) Keandalan dalam penangan masalah layanan pelayanan

3) Melaksanakan jasa dengan benar pada saat pertama bertemu

4) Menyediakan jasa pada waktu yang dijanjikan

5) Mempertahankan catatan bebas kesalahan

6) Karyawan mempunyai pengetahuan untuk menjawab pertanyaan pelanggan.

b. Daya tanggap (responsiveness) yaitu kemauan untuk membantu pelanggan dan memberiakan jasa dengan sendiri; indikatornya:

1) Selalu memberitahu pelanggan 
tentang kapan layanan akan

dilaksanakan

2) Layanan tepat waktu bagi pelanggan

3) Kesediaan untuk membantu pelanggan

4) Kesiapan untuk merespons permintaan pelanggan.

c. Jaminan (assurance) yaitu memiliki kecakapan dan pengetahuan yang diperlukan untuk mengerjakan jasa; indikatornya:

1) Karyawan yang menanamkan keyakinan pada pelanggan

2) Membuat pelanggan merasa aman dalam transaksi mereka

3) Karyawan yang selalu sopan

d. Empati (empathy) yaitu kemampuan melakukan upaya untuk mengenal kebutuhan pelanggan; indikatornya:

1) Memberikan perhatian pribadi kepada pelanggan

2) Karyawan yang menghadapi pelanggan dengan cara yang penuh perhatian

3) Mengutamakan kepentingan terbaik pelanggan
4) Karyawan yang memahami kebutuhan pelanggan

5) Jam bisnis yang nyaman.

e. Bukti fisik (tangible) yaitu penampilan fisik, peralatan, personal, material; indikatornya:

1) Peralatan modern

2) Fasilitas yang tampak menarik secara visual

3) Karyawan yang memilki penampilan rapi dan profesional

4) Bahan yang berhubungan dengan jasa mempunyai daya tarik visual.

\section{B. Kepuasan}

Arnould, menyatakan kepuasan adalah tingkat keputusan menyenangkan terkait terpenuhinya tingkat konsumsi yang sudah diatas harapan maupun masih dibawah harapan. Zeithaml (2003), mengartikan kepuasan adalah respon pelanggan karena terpenuhinya penilaian terhadap fitur produk/ jasa, atau pelayanan dari produk/jasa itu sendiri, mencapai tingkat menyenangkan terkait terpenuhinya konsumsi. 
Menurut Kotler (2009), kepuasan pelanggan adalah perasaan senang atau puas bahwa produk atau jasa yang diterima telah sesuai atau melebih harapan pelanggan; sedangkan kepuasan diartikan perasaan senang atau kecewa seseorang yang timbul karena membandingkan kinerja yang dipersepsikan produk/jasa (atau hasil) terhadap ekspektasi mereka.

Jika kinerja gagal memenuhi ekspektasi, pelanggan tidak puas. Jika kinerja sesuai dengan ekspektasi, pelanggan akan puas. Jika kinerja melebihi ekspektasi, pelanggan akan sangat puas atau senang. Kepuasan pelanggan merupakan tujuan dan sarana pemasaran, Perusahaan yang meraih tingkat kepuasan pelanggan yang tinggi memastikan pasar sasaran mereka mengetahui.

Penilaian pelanggan atas atas kinerja produk/jasa tergantung banyak faktor, terutama jenis hubungan loyalitas yang dimiliki pelanggan dengan sebuah merek. Pelanggan sering membentuk persespi yang lebih menyenangkan tentang sebuah produk/jasa dengan merek yang sudah mereka anggap posiitif.
Keputusan pelanggan untuk bersikap loyal atau bersikap tidak loyal merupakan akumulasi dari banyak perusahaan. Perusahaan akan bertindak bijaksana dengan mengukur kepuasan pelanggan secara teratur, karena salah satu kunci untuk mempertahankan pelanggan adalah kepuasan pelanggan. Pelanggan yang sangat puas biasanya tetap setia untuk waktu yang lebih lama. Kepuasan pelanggan yang lebih besar juga berhubungan dengan tingkat pengembalian yang lebih tinggi dari risiko yang lebih rendah di pasar saham.

Giese dan Cote, menyimpulkan definisi kepuasan pelanggan ada tiga komponen utama: (1) kepuasan pelanggan merupakan respon emosional atau kognitif; (2) respon tersebut menyangkut focus tertentu (ekspektasi, produk, pengalaman konsumsi, dan seterusnya); dan (3) respon terjadi pada waktu tertentu (setelah konsumsi, setelah pemilihan produk/jasa berdasarkan pengalaman akumulatif, dan lain-lain). Secara singkat, kepuasan pelanggan terdiri atas tiga pemilihan produk/jasa berdasarkan pengalaman 
akumulatif, dan pemilihan. Secara singkat, kepuasan pelanggan terdiri atas tiga komponen: respon, menyangkut focus tertentu yang ditentukan pada waktu tertentu.

1. Pengukuran Kepuasan Pelanggan Ada beberapa metode yang bisa dipergunakan setiap perusahaan untuk mengukur dan memantau kepuasan pelanggannya dan pelaggan pesaing. Kotler, mengidentifikasi empat metode untuk mengukur kepuasan pelanggan: sistem keluhan dan saran, ghost shooping (mystery shooping), loss customer analysis, dan kepuasan pelanggan.

1) Sistem keluhan dan saran

Perusahaan yang berorientasi pada pelanggan (customer oriented) perlu menyediakan kesempatan dan akses yang mudah dan nyaman bagi para pelanggannya guna menyampaikan saran, kritik, pendapat dan keluhan mereka. Media yang digunakan bisa berupa kotak saran, kartu komentar yang bisa dikirim via pos, saluran telepon khusus bebas pulsa, websites, dan lain-lain. Berdasarkan karakteristiknya, metode ini bersifatpasif karena perusahaan menunggu inisiatif pelanggan untuk menyampaikan keluhan atau pendapat sehingga sulit mendapatkan gambaran lengkap mengenai kepuasan atau ketidakpuasan pelanggan melalui cara ini semata. Tidak semua pelanggan yang tidak puas akan menyampaikan keluhannya. Dan masih menurut Kotler bahwa 25\% dari total pembelian konsumen diwarnai ketidakpuasan, namun kurang dari $5 \%$ pelanggan yang tidak puas bersedia melakukan komplain, kebanyakan diantaranya langsung berganti pemasok.

\section{2) Ghost Shooping (Mystery Shooping)}

Ghost Shooping (Mystery Shooping) yaitu cara memperoleh gambaran mengenai kepuasan pelanggan dengan mempekerjakan beberapa orang ghost shoopers untuk berperan atau berpura-pura sebagai pelanggan potensial produk/jasa perusahaan dan pesaing.Ghost shoopers diminta mengamati secara seksama dan menilai cara perusahaan dan pesaingnya melayani permintaan spesifik pelanggan, menjaab 
pertanyaan pelanggan, dan menangani setiap keluhan.

\section{3) Loss customer analysis}

Perusahaan seharusnya menghubungi pelanggan yang telah berhenti membeli atau yang telah pindah pemasok agar dapat memahmi mengapa hal itu terjadi dan supaya dapat mengambil kebijakan perbaikan atau penyempurnaan selanjutnya. Bukan hanya exit interview saja yang diperlukan, tetapi pemantauan customer loss rate juga penting karena customer loss rate menunjukkan kegagalan perusahaan dalam memuaskan pelanggannya.

\section{4) Survey Kepuasan Pelanggan}

Sebagian besar riset kepuasan pelanggan dilakukan dengan menggunakan metode survey, melalui survey perushaan akan memperoleh tanggapan dan balikan secara langsung dari pelanggan dan juga memberikan kesan positif bahwa perusahaan menaruh perhatian terhadap para pelanggannya. Pengukuran kepuasan pelanggan melalui metode ini dapat dilakukan dengan berbagai cara diantaranya:

(a) Directly reported staisfaction; pengukuran dilakukan menggunakan item-item spesifik yang menanyakan langsung tingkat kepuasan yang dirasakan pelanggan.

(b) Derived satisfaction, pertanyaan diajukan menyangkut dua hal uatama, yaitu tingkat harapan atau ekspektasi pelanggan terhadap kinerja produk/jasa perusahaan pada atribut-atribut relevan, dan persepsi pelanggan terhadap kinerja aktual produk jasa perusahaan (pengukuran model SERVQUAL)

(c) Problem analysis, responden diminta mengungkapkan masalahmasalah yang mereka hadapi berkaitan dengan produk/jasa perusahaan dan saran perbaikan, kemudian perusahaan akan melakukan analisis konten terhadap semua permasalahan dan saran perbaikan untuk mengidentifikasi bidang-bidang utama yang membutuhkan perhatian dan tindak lanjut segera.

(d) Importance performance analysis, responden diminta untuk 
menilai tingkat kepentingan berbagai atribut relevan dan tingkat kinerja perusahaan (perceived performance) pada masing-masing atribut tersebut.Cara ini bermanfaat untuk pedoman dalam megalokasikan sumber daya organisasi yang terbatas pada bidang-bidang spesifik, dimana perbaikan kinerja berdampak besar pada kepuasan pelanggan total.

\section{Faktor-Faktor yang Mempengaruhi} Kepuasan

Supriyanto (2010), menyatakan ada beberapa faktor yang berpegaruh pada kepuasan pelanggan, secara garis besar ada lima katagori, yaitu mutu produk (product quality), bagaimana pelanggan akan merasa puas atas jasa yang telah digunakan; mutu layanan (service quality), bagaimana konsumen akan merasa puas atas jasa yang telah dikonsumsinya - dimensi Servqual; faktor emosi (emotional factor), keyakinan akan rasa bangga terhadap produk/jasa yang digunakan dibandingkan dengan pesaing; harga (price), harga prduk/jasa yang diukur dari value/ nilai manfaat dibandingkan dengan biaya yang dikeluarkan pelanggan; dan biaya transport (cost of aquiring).

\section{Dimensi Kepuasan}

Menurut Zeithaml, ada beberap faktor yang mempengaruhi kepuasan pelanggan, antara lain: fitur produk dan jasa, emosi pelanggan, atribusi untuk keberhasilan atau kegagalan jasa, persepsi terhadap kewajaran dan keadilan (equity and fairness), pelanggan lain, keluarga, dan rekan kerja.

1) Fitur produk dan jasa, indikatornya meliputi produk yang berkualitas

2) Emosi pelanggan, indikatornya harga yang ditawarkan sebanding, dan biaya yang dapat ditolerir

3) Atribusi untuk keberhasilan atau kegagalan jasa, indikatornya meliputi pelayanan dilakukan profesional dan kepuasan pasien atas pelayananya

C. Hubungan Kualitas Pelayanan dengan Kepuasan

Menurut Kotler, kepuasan terjadi karena adanya perasaan senang atau kecewa seseorang yang timbul karena membandingkan kinerja (kualitas pelayanan) yang 
dipersepsikan dari produk/jasa.

Perusahaan harus meningkatkan ekspektasi dan menghantarkan kinerja yang sesuai harapan. Sehingga kepuasan dapat dirasakan dengan adanya kualitas pelayanan yang baik.

\section{Metode Penelitian}

Penelitian ini menggunakan metode kuantitatif dengan desain penelitian cross sectional. Populasi yang digunakan adalah mahasiswa FIKES UPNVJ dari tahun 2009 samapai dengan tahun 2013 berjumlah 1705 mahasiswa dari 5 program studi (Data dari KERMAWA UPNVJ 2014). Pengambilan sampel dilakukan secara purposive sampling yang seharusnya jumlah sampel yang diambil sebanyak 289 mahasiswa, namun kuesioner yang terkumpul 216 mahasiswa, karena tidak semua kuesioner dikembalikan lagi ke peneliti. .Pengambilan data sampel dilakukan saat pengumuman Yudisium kelulusan mahasiswa FIKES UPNVJ pada tanggal 18 September 2014, dengan jumlah 285 mahasiswa . S 1 Kperawatan 76 mahasiswa, Kesmas 52 mahsiswa, Ners 78 mahasiswa, D3 Fisioterafi 50 mahasiswa, D3
Keperawatan 29 mahasiswa.

Mahasiswa lulusan diberikan kuesioner mengenai pernyataan tentang kualitas pelayanan yang diberikan FIKES UPNVJ dan pernyataan tentang kepuasan mahasiswa lulusan. Pernyataan kualitas pelayanan diberikan pilihan jawaban dengan 5 Skala Likert (sangat baik, baik, cukup baik, kurang baik dan sangat tidak baik). Pernyataan kepuasan dalam skala likert (Sangat puas, puas, cukup puas, kurang puas dan sangat tidak puas). Analisa data yang digunakan secara regresi linier sederhana.

\section{Hasil Penelitian}

Jumlah data yang terkumpul sebanyak 216 sampel, yang terdiri dari: 45 mahasiswa lulusan Program Studi Kesehatan Masyarakat, 66 mahasiswa lulusan Program Studi $\quad$ S 1 Keperawatan, 40 mahasiswa lulusan Program Studi Ners, 24 mahasiswa lulusan D III Keperawaatn, dan 41 mahasiswa lulusan D III Fisioterafi.

\section{a. Lulusan Program Studi Kesehatan Masyarakat \\ Koefisien determinasi sebesar 89,8\% dari variasi kepuasan bisa dijelaskan}


oleh variabel tangible, responsiveness, emphaty, assurance, dan reliability, sedangkan sisanya $11,2 \%$ dijelaskan oleh sebab lain.

Persamaan regresi yang didapat :

$\mathrm{Y}=-0,268+(-0,370) \mathrm{X}_{1}+0,157 \mathrm{X}_{2}+$ $0,094 \mathrm{X}_{3}+0,631 \mathrm{X}_{4}+0,580 \mathrm{X}_{5}$

Konstanta sebesar -0,268 menyatakan bahwa jika tidak ada tangible, responsiveness, emphaty, assurance, dan realbility maka kepuasan adalah 0,268. Koefisien regresi $\mathrm{X}_{1}$ menyatakan bahwa setiap pengurangan 1 point tangible akan menurunkan kepuasan mahasiswa sebesar 0,0370.Koefisien regresi $\mathrm{X}_{2}$ menyatakan bahwa setiap penambahan 1 point responsiveness akan meningkatkan kepuasan mahasiswa sebesar 0,157 . Koefisisen regresi $\mathrm{X}_{3}$ menyatakan bahwa setiap penambahan 1 point emphaty akan meningkatkan kepuasan sebesar 0,094. Koefisien regresi $\mathrm{X}_{4}$ menyatakan bahwa setiap penambahan 1 point assurance akan meningkatkan kepuasan sebesar 0,0631. Koefisien regrasi $\mathrm{X}_{5}$ menyatakan bahawa setiap penambahan 1 point reliability akan meningkatkan kepuasan sebesar 0,580 .

Hasil uji t, tangibel berpengaruh positif terhadap kepuasan dengan nilai t hitung $-3,124$ dan probabilitas 0,03 dibawah 0,05,. Responsiveness berpengaruh positif dan signifikan terhadap kepuasan dengan nilai $t$ hitung 2,422 dan probabilitas sebesar 0,020. Emphaty berpengaruh positif terhadap kepuasan dengan nilai $t$ hitung 2,591 dan probabilitas sebesar 0,013. Assurance dengan $\mathrm{t}$ hitung 5,317 probabilitas 0,000 . Reliability dengan t hitumg 3,425 dan probabilitas 0,001. Kelima koefisien regresi signifikan terhadap kepuasan Kesimpulan bahwa dimensi Assurance faktor utama penentu kepuasan mahasiswa, diikuti reliability, responsiveness, emphaty, serta tangibel

\section{b. Lulusan Program Studi Ners}

Koefisien determinasi sebesar 99,1\% dari variasi kepuasan bisa dijelaskan oleh variabel tangible, responsiveness, emphaty, assurance, dan reliability, sedangkan sisanya $0,0,9 \%$ dijelaskan oleh sebab lain.

Persamaan regresi yang didapat : 
$\mathrm{Y}=0,010+(-0,071) \mathrm{X}_{1}+0,520 \mathrm{X}_{2}+$

$0,155 \mathrm{X}_{3}+0,473 \mathrm{X}_{4}+(-0,074) \mathrm{X}_{5}$

Hasil uji t, tangibel berpengaruh positif terhadap kepuasan dengan nilai t hitung -3,860 dan probabilitas 0,000 dibawah 0,05,. Responsiveness berpengaruh positif dan signifikan terhadap kepuasan dengan nilai $t$ hitung 10,251 dan probabilitas sebesar 0,000 Emphaty berpengaruh positif terhadap kepuasan dengan nilai $t$ hitung 2,725 dan probabilitas sebesar 0,010. Assurance dengan t hitung 9,946 probailitas 0,000. Reliability dengan $t$ hitung $-2,602$ dan probabilitas 0,014. Kelima koefisien regresi signifikan terhadap kepuasan. Kesimpulan bahwa dimensi assurance faktor utama penentu kepuasan mahasiswa, diikuti responsiveness, emphaty, reliability serta tangibel.

\section{c. Lulusan Program Studi $S 1$ \\ Keperawatan}

Koefisien determinasi sebesar 65,2\% dari variasi kepuasan bisa dijelaskan oleh variabel tangible, responsiveness, emphaty, assurance, dan reliability, sedangkan sisanya 34,8\% dijelaskan oleh sebab lain.

Persamaan regresi yang didapat :

$$
\begin{aligned}
\mathrm{Y}= & 0,152+0,838 \mathrm{X}_{1}+0,270 \mathrm{X}_{2}+ \\
& 0,379 \mathrm{X}_{3}+(-0,833) \mathrm{X}_{4}+0,380 \mathrm{X}_{5}
\end{aligned}
$$

Hasil uji t, tangibel berpengaruh positif terhadap kepuasan dengan nilai t hitung 3,326 dan probabilitas 0,023 dibawah 0,05,. Responsiveness berpengaruh positif dan signifikan terhadap kepuasan dengan nilai $t$ hitung 2,333 dan probabilitas sebesar 0,023 Emphaty berpengaruh positif terhadap kepuasan dengan nilai $\mathrm{t}$ hitung 3,383 dan probabilitas sebesar 0,001. Assurance dengan $\mathrm{t}$ hitung 9,946 probailitas 0,000 . Reliability dengan $t$ hitung $-2,643$ dan probabilitas 0,013. Kelima koefisien regresi signifikan terhadap kepuasan.

Kesimpulan bahwa dimensi tangibel faktor utama penentu kepuasan mahasiswa, diikuti emphaty, realability, responsiveness, Assurance.

\section{d. Lulusan Program Studi D III Keperawatan}

Koefisien determinasi sebesar 95,5\% dari variasi kepuasan bisa dijelaskan oleh variabel tangible, responsiveness, emphaty, assurance, dan reliability, 
sedangkan sisanya $4,5 \%$ dijelaskan oleh sebab lain.

Persamaan regresi yang didapat :

$$
\begin{gathered}
\mathrm{Y}=(-1,424)+0,784 \mathrm{X}_{1}+0,830 \mathrm{X}_{2}+ \\
0,257 \mathrm{X}_{3}+(-0,591) \mathrm{X}_{4}+ \\
0,153 \mathrm{X}_{5}
\end{gathered}
$$

Hasil uji t, tangibel berpengaruh positif terhadap kepuasan dengan nilai t hitung 9,069 dan probabilitas 0,000 dibawah 0,05,. Responsiveness berpengaruh positif dan signifikan terhadap kepuasan dengan nilai $t$ hitung 13,082 dan probabilitas sebesar 0,000 Emphaty berpengaruh positif terhadap kepuasan dengan nilai $\mathrm{t}$ hitung 3,597 dan probabilitas sebesar 0,002. Assurance dengan $\mathrm{t}$ hitung ($6,744)$ probailitas 0,000 . Reliability dengan t hitung 2,554 dan probabilitas 0,020. Kelima koefisien regresi signifikan terhadap kepuasan.

Kesimpulan bahwa dimensi responsiveness, faktor utama penentu kepuasan mahasiswa, diikuti tangibel, emphaty, reliability, Assurance.

\section{e. Lulussan Program Studi D III}

\section{Fisioterafi.}

Koefisien determinasi sebesar 98,1\% dari variasi kepuasan bisa dijelaskan oleh variabel tangible, responsiveness, emphaty, assurance, dan reliability, sedangkan sisanya 1,9\% dijelaskan oleh sebab lain. Persamaan regresi yang didapat :

$\mathrm{Y}=(-0,188)+0,103 \mathrm{X}_{1}+0,121 \mathrm{X}_{2}+$ $(-0,177) \mathrm{X}_{3}+0,515 \mathrm{X}_{4}+0,505 \mathrm{X}_{5}$

Hasil uji t, tangibel berpengaruh signifikan terhadap kepuasan dengan nilai t hitung 2,794 dan probabilitas 0,008 diatas 0,05. Responsiveness berpengaruh signifikan terhadap kepuasan dengan nilai $\mathrm{t}$ hitung 2.655 dan probabilitas sebesar 0,012. Emphaty berpengaruh signifikan terhadap kepuasan dengan nilai $\mathrm{t}$ hitung -4,549 dan probabilitas sebesar 0,000.. Assurance dengan t hitung 6,069 probailitas 0,000 . Relialibility dengan $\mathrm{t}$ hitung

5,390 dan probabilitas 0,000. Kelima koefisien regresi memiliki pengaruh signifikan terhadap kepuasan. Kesimpulan bahwa dimensi Assurance faktor utama penentu kepuasan mahasiswa, diikuti reliability, responsiveness, tangibel, emphaty.

\section{f. Hasil regresi keselurahan}

\section{Program Studi}


$\mathrm{Y}=0,112+0,023 \mathrm{X}_{1}+0,243 \mathrm{X}_{2}+$ $0,226 X_{3}+0,283 X_{4}+0,222 X_{5}$

Hasil uji t, tangibel tidak berpengaruh signifikan terhadap kepuasan dengan nilai t hitung 0.426 dan probabilitas 0,670 di atas 0,05,. Responsiveness berpengaruh sangat signifikan terhadap kepuasan dengan nilai $t$ hitung 4.888 dan probabilitas sebesar 0,000. Emphaty berpengaruh sangat signifikan terhadap kepuasan dengan nilai t hitung 5.176 dan probabilitas sebesar 0,000. Assurance dengan $\mathrm{t}$ hitung 4.397 probabilitas $\quad 0,000$ berpengaruh sangat sinifikan terhadap kepuasan mahasiswa. Reliability dengan t hitung 3.684 dan probabilitas 0,000 berpengaruh sangat signifikan terhadap kepuasan mahasiswa. Kelima koefisien regresi memiliki pengaruh sangat signifikan terhadap kepuasan mahasiswa.

\section{Pembahasan}

Berdasarkan atas hasil analisa data, serta kajian teori dan hasil penelitian sebelumnya, maka diperoleh pembahasan sebagai berikut:

Variabel kualitas pelayanan berpengaruh positif terhadap kepuasan mahasiswa FIKES UPNVJ, terutama dimensi responsiveness, emphaty, assurance dan reliability. Hasil penelitian ini tidak sependapat dari hasil penelitian Prasetyaningrum (2009), yang menjelaskan terdapat pengaruh positif kualitas pelayanan terhadap kepuasan mashasiswa pada UNDARI Ungaran.

Hasil penelitian di FIKES UPNVJ ini juga tidak sejalan dengan teori yang disampaikan Zeithaml (2003) yang mengemukakan teori tentang pengaruh antara kualitas pelayanan jasa dan kepuasan pelanggan, dimana kualitas jasa yang memadai maka pelanggan akan senang dan menilai kualitas jasa tersebut adalah tinggi. Sedangkan menurut Kotler (2009) kepuasan pelanggan adalah suatu tingkatan dimana produk dirasakan sesuai dengan kebutuhan, keinginan dan harapan pelanggan, bahkan melampaui harapannya.

Penelitian yang dilakukan di FIKES UPNVJ hampir mirip dengan penelitian Rinala, IN (2012), bahwa hanya empat dimensi kualitas pelayanan berpengaruh signifikan terhadap kepuasan mahasiswa STP Nusa Dua Bali, sedangkan dimensi assurance ternyata tidak berpengaruh 
signifikans terhadap kepuasan

mahasiswa.

Dimensi tangibel yang tidak berpengaruh signifikans terhadap kepuasan mahasiswa, hal ini terjadi di FIKES UPNVJ karena bukti fisik merupakan faktor pemicu awal persepsi seseorang dalam menilai sebuah kualitas pelayanan, karena secara umum melihat fisik nyata merupakan bukti konkrit dari pelayanan lainnya. Fasilitas fisik yang ada di FIKES UPNVJ sebagai fasilitas pendukung proses pembelajaran seperti laboraturium, perpustakaan, computer on line yang kurang memadai merupakan hal nyata yang bisa dilihat oleh mahasiswa dan dinilai kurang oleh mahasiwa.

\section{Kesimpulan}

Kesimpulan penelitian ini adalah dimensi responsiveness, emphaty, assurance, dan reliability berpengaruh signifikan positif terhadap kepuasan mahasiswa Fikes UPN "Veteran" Jakarta, sedangkan dimensi tangible tidak berpengaruh signifikan terhadap kepuasan mahasiswa. Dimensi yang paling penting pengaruhnya terhadap kepuasan mahasiswa yaitu Assurance, kemudian secara berurutan diikuti oleh dimensi emphaty, responsiveness, dan reliability yang hampir sama pentingnya.

\section{Saran}

Saran perlu dtingkatkan bukti fisik berupa perpustakaan, laboraturium praktek, dan computer berbasis on line penting bagi mahasiswa untuk mendukung proses pembelajaran mahasiswa agar kepuasan mahasiswa terpenuhi.

\section{Daftar Pustaka}

Kotler, P dan Keller, K.L. (2009). Marketing Management. $13^{\text {th }} \mathrm{Ed}$. New Jersey: Pearson Prentice Hall

Lavelock, C.H. dan Wright, L.K. (2007). Manajemen Pemasaran Jasa. Edisi Bahasa Indonesia. Jakarta: Erlangga

Prasetyaningrum, ID..( 2009). Analisis Pengaruh Pembelajaran dan Kualitas Pelayanan Terhadap Kepuasan Mahasiswa dan Loyalitas Mahasiswa (Studi Kasus Pada Undaris Ungaran). Tesis Program Magister Manajemen, Universitas Diponegoro.

Rinala, IN, Yudana, IM dan Natajaya, IN (2012). Pengaruh Kualitas Pelayanan Akademik Terhadap Kepuasan dan Loyalitas Mahasiswa Pada Sekolah Tinggi 
Pariwisita Nusa Dua Bali. EJournal Program Pascasarjana Universitas Pendidikan Ganesha Program Studi Administrasi Pendidikan Vol. 4 Tahun 2013.

Supriyanto, S. dan Ernawaty. (2010). Pemasaran Industri Jasa Kesehatan Yogyakarta: Andi Offset

Zeithaml and Bitner. (2003). Service Marketing.Integrating Customer Focus Across The Firm. New York: The Mc Graw Hill Company 